\title{
Effects of hemoperitoneum on wound healing and fibrinolytic activity in colonic anastomosis
}

\author{
Hemoperitoneumun kolon anastomozlarında yara iyileşmesine ve \\ fibrinolitik aktivite üzerine etkisi
}

\author{
Neşet KÖKSAL, ${ }^{1}$ Mehmet Ali UZUN, ${ }^{2}$ Ömer Faruk ÖZKAN, ${ }^{2}$ Münire KAYAHAN, ${ }^{2}$ \\ Osman Metin İPÇİOĞLU, ${ }^{3}$ Yusuf GÜNERHAN, ${ }^{1}$ Ersin ERGÜN, ${ }^{2}$ Pembegül GÜNEŞ ${ }^{4}$
}

\section{BACKGROUND}

We aimed to test whether hemoperitoneum has adverse effects on colonic anastomosis healing by increasing fibrinolytic activity.

\section{METHODS}

After colonic intersection and anastomosis, 20 Wistar Albino rats received intraabdominal injections of either $25 \mathrm{mg} /$ $\mathrm{kg}$ blood (10, Group 1) or physiologic saline (10, Group 2). Anastomotic bursting pressures were measured after sacrifice on the fifth day. Following histopathological evaluation of the anastomotic line, hydroxyproline, tissue plasminogen activator (tPA), plasminogen activator inhibitor-1 (PAI-1), and tPA/PAI-1 complex levels were determined in the omentum, lung and anastomotic colon.

\section{RESULTS}

Mean anastomotic bursting pressures of Groups 1 and 2 were $224.5 \mathrm{mmHg}$ and $254.4 \mathrm{mmHg}(\mathrm{p}=0.121)$, and mean hydroxyproline levels were 45.89 and $65.959 \mathrm{mg} / \mathrm{g}$ protein, respectively $(\mathrm{p}=0.257)$. Histopathology was insignificant. There was a significant difference between groups in omental tPA levels $(0.962 \mathrm{ng} / \mathrm{ml}$ and $0.27 \mathrm{ng} / \mathrm{ml}, \mathrm{p}=0.041)$, but not in PAI-1 and tPA/PAI-1. Anastomotic line and lung levels of tPA, PAI-1 and tPA/PAI-1 complex were not significantly different between groups. The relation between anastomotic line tPA level and bursting pressure was highly significant in Group $2(\mathrm{r}=0.778 ; \mathrm{p}=0.008)$.

\section{CONCLUSION}

In this first study on the effect of hemoperitoneum on colonic anastomosis, we observed no significant effect on anastomotic healing or fibrinolytic activity, except in the omentum. Further studies with different blood volumes and assessment times are needed.

Key Words: Colonic anastomosis; fibrinolysis; hemoperitoneum; wound healing.

\section{$\boldsymbol{A M A C}$}

Kolon anastomozlarında iyileşme ve fibrinolitik aktivite üzerine hemoperitoneumun etkisi araştırıldı.

\section{GEREÇ VE YÖNTEM}

Wistar Albino cinsi 20 sıçanda, kolon kesilip anastomoz yapıldıktan sonra 10 sıçana (Grup 1) karın içine verici sıçanlardan alınan kan (25 ml/kg), 10 sıçana (Grup 2) ise serum fizyolojik verildi. Sıçanlar beşinci gün sakrifiye edilerek anastomoz patlama baçınçları ölçüldü. Anastomoz hattının histopatolojik değerlendirilmesi yapılarak, omentum, akciğer ve anastomoz hattında hidroksiprolin, doku plazminojen aktivatörü (tPA), plazminojen aktivatör inhibitörü-1 (PAI 1) ve tPA/PAI 1 kompleksi düzeyleri saptandi.

\section{BULGULAR}

Anastomoz patlama basinci Grup 1'de 224,5 mmHg, Grup 2 'de $254,4 \mathrm{mmHg}$ idi $(\mathrm{p}=0,121)$. Hidroksiprolin değerleri Grup 1 ve Grup 2'de sirasiyla 45,89 ve 65,959 mg/gr protein olarak bulundu $(\mathrm{p}=0,257)$. Histopatolojik incelemede anlamlı farklılık saptanmadı. Omentum tPA değeri Grup 1 'de 0,962 ng/ml, Grup 2'de 0,27 ng/ml olup, fark anlam11 idi $(p=0,041)$. Omentum PAI 1 ve tPA/PAI 1 kompleksi değerleri, anastomoz ve akciğer dokuları tPA, PAI 1 ve tPA/PAI 1 kompleksi değerleri açısından gruplar arasındaki fark anlamlı değildi. Grup 2'de anastomoz hattı tPA değeri ile anastomoz patlama basıncı arasındaki ilişki yüksek düzeyde anlamlı idi $(\mathrm{r}=0,778 ; \mathrm{p}=0,008)$.

\section{SONUÇ}

Kolon anastomozlarında hemoperitoneumun etkisini araştıran bu ilk çalışmada, anastomoz iyileşmesinde ve omentum haricinde fibrinolitik aktivitede anlamlı fark gözlenmedi. Farklı kan volümleri ve farklı değerlendirme zamanları ile yapılacak yeni çalışmalara ihtiyaç vardır.

Anahtar Sözcükler: Kolon anastomozu; fibrinolizis, hemoperitoneum; yara iyileşmesi.

\footnotetext{
${ }^{1}$ Department of General Surgery, Kafkas University Faculty of Medicine

Kars; Departments of ${ }^{2}$ 2nd General Surgery, ${ }^{4}$ Pathology, Haydarpasa

Numune Training and Research Hospital, Istanbul; ${ }^{3}$ Biochemistry and Clinical Biochemistry Unit, GATA Haydarpasa Training Hospital, Istanbul, Turkey.
} 
Anastomotic leakage after colon resection remains a significant problem and a major cause of postoperative morbidity and mortality. In large series, it has been reported to be associated with $25-37 \%$ of deaths.$^{[1]}$ Intraabdominal hemorrhage is the other complication that can develop during and/or after the operation. Its effects on hemodynamics and tissue perfusion are well known and appropriately struggled with. However, the potential effects of hemoperitoneum on colonic anastomosis healing have been neglected.

Yamamoto et al. ${ }^{[2]}$ demonstrated that hemoperitoneum caused an increase in fibrinolytic activity. Increased fibrinolytic activity was also reported to result in adverse effects on wound healing. ${ }^{[3-5]}$

In this study, we aimed to analyze whether hemoperitoneum caused unwanted effects on wound healing in colonic anastomosis by increasing fibrinolytic activity.

\section{MATERIALS AND METHODS}

With the approval of the local Ethics Committee, this study was conducted in the Experimental Research and Animal Laboratory of Haydarpasa Numune Training and Research Hospital by investigators from the Second Department of General Surgery. Histopathological examinations were performed in the Pathology Unit of Haydarpasa Numune Training and Research Hospital. Photometric and enzyme-linked immunosorbent assay (ELISA) measurements were done in the Biochemistry Unit of GATA Haydarpasa Training Hospital.

In this experimental study, 30 female Wistar Albino rats were used. Rats were housed at $24^{\circ} \mathrm{C}$ with a $12-$ hour (h) light-dark cycle. The average weight of the 20 rats used for the experiment was $210 \mathrm{~g}$ (range: 180$260 \mathrm{~g}$ ). Ten more rats were used as donors. Anesthesia was achieved with intraperitoneal administration of 75 $\mathrm{mg} / \mathrm{kg}$ ketamine $\mathrm{HCl}$ (Ketalar ${ }^{\circledR}$ Flacon; Pfizer Pharmaceutical Co, Istanbul, Turkey) and $10 \mathrm{mg} / \mathrm{kg}$ xylazine $\mathrm{HCl}$ (Basilazin Flacon; Bavet Drug Co, Istanbul, Turkey). Laparotomy was performed through a $3-\mathrm{cm}$ midline incision. The descending colon was intersected completely at a level $3 \mathrm{~cm}$ proximal to the peritoneal reflection. An inverted single-layer end-to-end anastomosis was constructed with eight interrupted sutures with 6/0 polypropylene (ProleneTM). After completion of the anastomosis, hemoperitoneum was formed in 10 randomly chosen rats (Group 1: hemoperitoneum group) with $25 \mathrm{ml} / \mathrm{kg}$ blood given intraperitoneally, which was obtained from donor rats through the intracardiac route and then cross-matched.

The remaining 10 rats received $25 \mathrm{ml} / \mathrm{kg}$ physiologic saline, intraperitoneally, following completion of the anastomosis (Group 2: control group). Laparot- omy incisions were closed in two layers with continuous $3 / 0$ silk sutures. All the rats were sacrificed on the postoperative fifth day with laparotomy. Inspection for anastomotic dehiscence and local peritonitis, which was defined as the macroscopic sign of inflammation, and hypervascularity was performed. The colon was occluded $2 \mathrm{~cm}$ proximal to the anastomosis through ligation with a $3 / 0$ silk. The tip of a cannula, the outer end of which was connected to a volume-directed infusion pump filled with physiologic saline, was inserted into the anal canal and pushed forward to the lumen of the anastomosis. A perianal circular suture with 3/0 silk was ligated to fix the cannula. The side arm of the cannula was connected to a pressure transducer, which in turn was connected to a monitor. The occluded colonic segment was gradually filled with physiologic saline at a constant rate of $150 \mathrm{ml} / \mathrm{h}$ while the intraluminal pressure was monitored until burst occurred, as indicated as an abrupt loss of pressure. The bursting pressures (BPs) were documented.

The 1-cm colonic segment containing the anastomosis was excised and opened longitudinally, and after being washed under physiologic saline, was blotted. The region of anastomosis was separated into three longitudinal pieces with a knife. Two pieces were placed into the Eppendorf tubes and frozen at $-80^{\circ} \mathrm{C}$, while the other was put into formol for histopathological evaluation. Tissue samples obtained from the omentum and lungs by thoracotomy were blotted again after being washed with physiologic saline. They were also placed into Eppendorf tubes and frozen at $-80^{\circ} \mathrm{C}$.

Histopathological examination of the line of anastomosis was performed by the same pathologist, who was blinded to the groups. Each side was examined and evaluated by grading based on the presence of erythrocytes, polymorphonuclear cells, mononuclear cells, fibroblasts, collagen fibers, and fibrin, as follows: 0 for no evidence, 1 for occasional evidence, $2+$ for light scattering, $3+$ for abundance, and $4+$ for confluence of cells or fibers, as described previously. ${ }^{[6]}$ Hydroxyproline, tissue plasminogen activator (tPA), plasminogen activator inhibitor-1 (PAI-1) and tPA/PAI-1 complex levels were measured at the line of anastomosis. Levels of tPA, PAI-1 and tPA/PAI-1 complex were also determined in the omentum for intraabdominal fibrinolytic activity and in lung tissue for the systemic fibrinolytic activity.

\section{Biochemical Analysis}

After measurement of dry weights of the samples, they were buffered with potassium phosphate and placed in homogenizers (Ultra-Turrax T-25 model, Janke\&Kugel, Staufen, Germany) at $1000 \mathrm{U}$ for 3 minutes (min) in order to obtain homogeneity as 1 
Table 1. Comparison of mean anastomotic bursting pressures and hydroxyproline values of the groups

\begin{tabular}{lccc}
\hline & Group 1 & Group 2 & \\
& Mean \pm SD & Mean \pm SD & p \\
\hline Bursting pressure (mmHg) & $224.5 \pm 65.389$ & $254.4 \pm 63.325$ & 0.121 \\
Hydroxyproline (mg/g protein) & $45.89 \pm 28.324$ & $65.959 \pm 30.706$ & 0.257 \\
\hline
\end{tabular}

Table 2. Summary of histological examination of the anastomosis lines

\begin{tabular}{lccc}
\hline Parameter & $\begin{array}{c}\text { Group 1 } \\
\text { Mean } \pm \text { SD }\end{array}$ & $\begin{array}{c}\text { Group 2 } \\
\text { Mean } \pm \text { SD }\end{array}$ & p \\
\hline Erythrocytes & $0.575 \pm 0.442$ & $0.7 \pm 0.587$ & 0.812 \\
Polymorphonuclear cells & $1.7 \pm 0.654$ & $1.375 \pm 0.592$ & 0.134 \\
Mononuclear cells & $1.575 \pm 0.667$ & $1.65 \pm 0.615$ & 0.619 \\
Fibroblasts & $1.825 \pm 0.764$ & $1.85 \pm 0.679$ & 0.879 \\
Collagen fibers & $0.775 \pm 0.546$ & $1.25 \pm 0.391$ & 0.051 \\
Fibrin & $1.225 \pm 0.702$ & $0.925 \pm 0.678$ & 0.213 \\
\hline
\end{tabular}

$\mathrm{ml} / 70 \mathrm{mg}$ dry weight tissue. Then, they were placed in a sonicator (Bandelin Electronic, Berlin, Germany) for $30 \mathrm{~min}$. Homogenates obtained at the end of this period were centrifuged at $+4^{\circ} \mathrm{C}$ for $10 \mathrm{~min}$ at $6000 \mathrm{~g}$ with formation of supernatants. Levels of fibrinolytic components were measured in prepared tissue extracts. For determination of tPA, PAI-1 and tPA/PAI1 complex levels in the supernatants, micro ELISA method was used (ASSAYPRO ${ }^{\circledR}$ Plasma tPA ELISA, Universal Biologicals (Cambridge) Ltd., Cambridge, UK). Absorbance values were determined by KaytoMicroplate Reader RT 2100 C (Fayto Electronic Inc., China). Standard lines were drawn, with the absorbance values measured corresponding to standard concentrations. Concentrations of tPA, PAI- 1 and tPA/ PAI-1 complex were calculated by placing the absorbance values in the formula of the linear equation. Protein content of the tissue samples was measured by Lowry method..$^{[7]}$ Results of tPA, PAI-1 and tPA/ PAI-1 complex were expressed as ng/mg protein. The procedure for the measurement of hydroxyproline was based on alkaline hydrolysis of the tissue homogenate and subsequent determination of free hydroxyproline in hydrolysates. ${ }^{[7]}$ Chloramine-T was used to oxidize free hydroxyproline for the production of a pyrrole. With the addition of Ehrlich's reagent, a chromophore was produced that can be measured at $550 \mathrm{~nm}$. Optimal assay conditions were determined using tissue homogenate and purified acid soluble collagen along with standard hydroxyproline. ${ }^{[8]}$ Results were calculated as $\mu \mathrm{g} / \mathrm{mg}$.

\section{Statistical Analysis}

The Statistical Package for the Social Sciences (SPSS) program for Windows 15.0 was used for sta- tistical analysis. For evaluation of the data, descriptive statistical methods (mean, standard deviation) were used together with Mann-Whitney U test for comparison of quantitative data, chi-square test for comparison of qualitative data, and Pearson's correlation for the search of the relationship between variables. Results were evaluated within $95 \%$ confidence interval, and values of $\mathrm{p}<0.05$ were accepted as significant.

\section{RESULTS}

No anastomotic dehiscence or local peritonitis was detected in any of the rats sacrificed. Hydroxyproline levels of the anastomotic line and BP measured to evaluate wound healing in anastomosis are shown in Table 1 and histopathological findings of the anastomotic line in Table 2. Mean BP was $224.5 \mathrm{mmHg}$ in Group 1 and $254.4 \mathrm{mmHg}$ in Group 2 ( $\mathrm{p}=0.121)$. Mean hydroxyproline levels of Groups 1 and 2 were 45.89 and $65.959 \mathrm{mg} / \mathrm{g}$ protein, respectively $(\mathrm{p}=0.257)$. There were no significant histopathological differences between groups.

Levels of tPA, PAI-1 and tPA/PAI-1 complex determined to evaluate the fibrinolytic activity in the anastomotic line, omentum and lung tissue of each group are reported in Table 3.

Omental tPA value was $0.962 \mathrm{ng} / \mathrm{ml}$ in Group 1 and $0.27 \mathrm{ng} / \mathrm{ml}$ in Group 2, and the difference was statistically significant $(p=0.041)$; however, there was no significant differences between the two groups regarding the other parameters. Among the relationships between all values measured, only the relation between tPA levels of the anastomotic line and anastomotic BP in Group 2 was highly significant $(r=0.778 ; p=0.008)$. 
Table 3. Levels of tPA, PAI-1 and tPA/PAI-1 complex in the anastomotic line, omentum and lung tissue of the groups

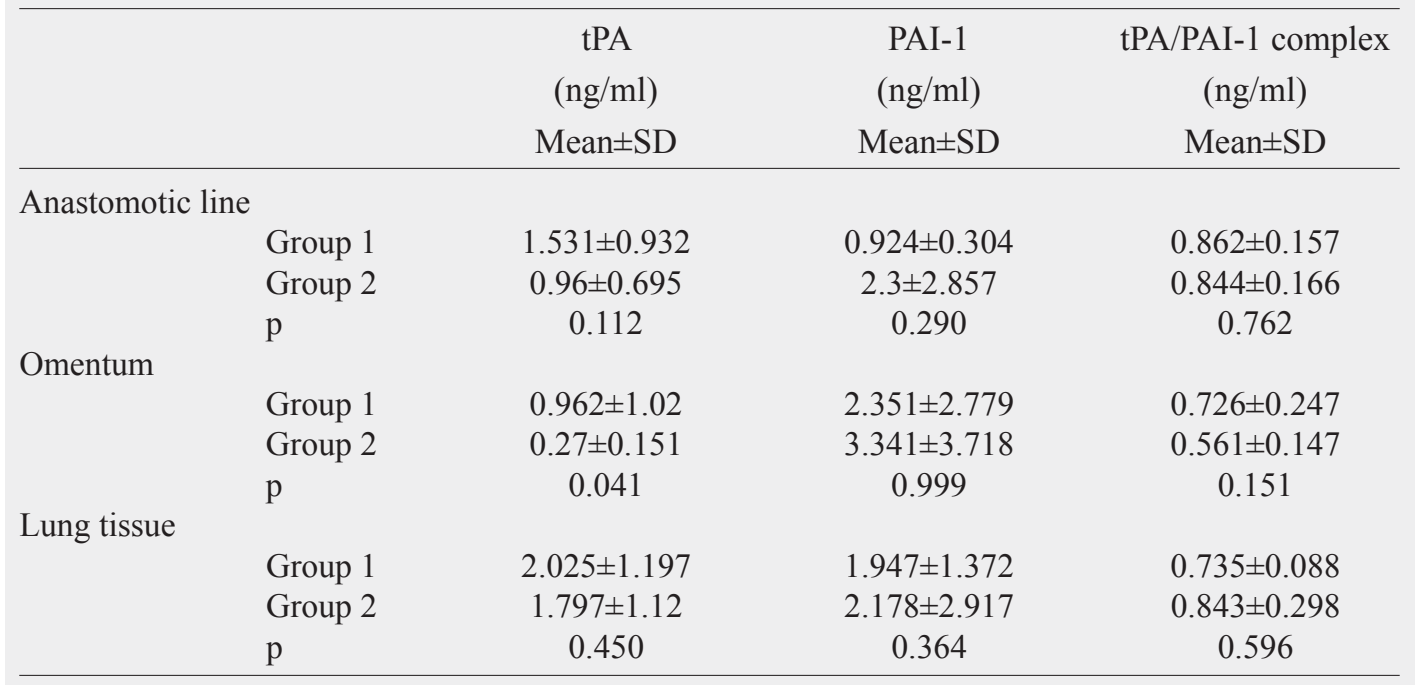

\section{DISCUSSION}

The effect of hemoperitoneum on fibrinolytic activity was investigated by Yamamoto et al. ${ }^{[2]}$ In their study, $100 \mathrm{ml} / \mathrm{kg}$ blood obtained from donor rats was given to the rats of the hemoperitoneum group, intraperitoneally, while the control group received the same amount of physiologic saline. The rats were sacrificed on the fourth day, and in the hemoperitoneum group, fibrinolytic activity was found to be increased significantly in the omentum and lung tissue, which reflected the local and systemic fibrinolytic activity, respectively. They connected these results with the development of re-bleeding in patients with blunt trauma who were followed up or treated without operation, and this had been the starting point for our hypothesis. For the determination of fibrinolytic activity, we used tPA, PAI1 and tPA/PAI-1 complex values instead of the fibrin plate method used by those authors. tPA is the main plasminogen activator and its activity is restricted by plasminogen activating inhibitors, predominantly PAI1. They come together to form inactive complexes that limit the activity of IPA and therefore the fibrinolytic activity.

There is a covariance between PAI- 1 and tPA/PAI1 complex values. ${ }^{[9,10]}$ In our study, omental PAI-1 and tPA/PAI-1 complex values did not vary significantly between Group 1 and Group 2, but tPA values were significantly higher in Group 1 than Group 2. This can be interpreted as indicating that hemoperitoneum increases the fibrinolytic activity in the omentum. The fibrinolytic activity parameters determined in the anastomotic line for the effect on anastomosis and in lung tissue for the systemic effect revealed that although tPA values of Group 1 were higher than those of Group 2, there was no significant difference between the groups for either tPA values or for tPA/PAI-1 complex values. Our findings of increased fibrinolytic activity in the omentum were consistent with the results obtained by Yamamoto et al., ${ }^{[2]}$ but we could not demonstrate the same finding in lung tissue. When comparing the results, the differences in blood volume used to produce hemoperitoneum and in time to assessment should be kept in mind. We used less blood $(25 \mathrm{ml} / \mathrm{kg}$ versus 100 $\mathrm{ml} / \mathrm{kg}$ ) in order to decrease the number of donor rats used, and sacrificed rats at a later time ( 5 days versus 4 days) to evaluate synchronous wound healing of the anastomoses.

In the literature, fibrinolytic activity was assessed more commonly in studies evaluating development of intraabdominal adhesions, and different results at different assessment times were reported. ${ }^{[11-14]}$ In those studies, peritoneal fluid and peritoneal samples with adhesive tissues were generally used, which do not match with our experimental model.

Several factors can influence the healing process in colonic anastomosis. Preoperative factors include gender, malnutrition (anemia, hypoalbuminemia), weight loss, and cardiovascular disease, while surgeryrelated factors include long operation time, intraoperative blood loss requiring multiple blood transfusions, intraoperative contamination of the operative field, level of the anastomosis, adequate tissue perfusion in anastomosis, tension-free anastomosis, and the surgeon's experience in colorectal surgery. ${ }^{[15,16]}$ The effect of hemoperitoneum, however, has not been searched yet, and our study is the first in this field.

The extracellular matrix (ECM), in particular the collagen metabolism and its potential disturbance, is an important factor influencing the outcome of anastomotic healing in the intestines. ${ }^{[17,18]}$ The matrix metal- 
loproteinases (MMPs), which are structurally related neutral proteinases, can degrade almost all ECM components and play an important role in wound healing and remodeling of the ECM. ${ }^{[19]}$ In animal experiments and a clinical research, a direct correlation between increased MMP expression and anastomotic leakage was demonstrated..$^{[5,20]}$ Plasmin and tissue activator of plasminogen, which act as structural elements of the fibrinolytic activity, contribute to the activation of collagenase (MMP-1), resulting in increased degradation of ECM proteins, such as collagen. ${ }^{[4]}$

Thrombin-activatable fibrinolysis inhibitor (TAFI) is a procarboxypeptidase that is synthesized in the liver. Activated TAFI can downregulate fibrinolysis by removing carboxyterminal lysines from fibrin, which act as binding sites for plasminogen and tPA. In a pulmonary clot lysis model, it was demonstrated that fibrinolysis was significantly increased in TAFI knockout rats. ${ }^{[21]}$ te Velde et al..$^{[3]}$ demonstrated that wound healing was disturbed both in cutaneous wounds and colonic anastomosis in mice lacking TAFI, and they concluded that it was due to the increased fibrinolytic activity resulting in unbalanced matrix degradation. In addition to those findings supporting our hypothesis, Cohen et al. ${ }^{[22]}$ administered single-dose infusion of neurokinin-1 receptor antagonist intraperitoneally during and $1,5,12$, and $24 \mathrm{~h}$ after the operation. They measured peritoneal tPA activity at $24 \mathrm{~h}$ after the procedure, and observed the adhesion formation and anastomotic BP 7 days after the operation. Increase in peritoneal tPA activity was associated with a decrease in adhesion formation in 1- and 5-h trials, but in the 12-h trial, there was no difference in either tPA activity or adhesion formation. No significant decrease was recorded in the anastomotic BP in either group, and this could be because of administration of neurokinin-1 receptor antagonist at an early phase and as a single dose. In our study, there was a highly significant relationship between the anastomotic line tPA value and the BP in Group 2, but the relation could not be demonstrated in Group 1.

Both the anastomotic BPs and the hydroxyproline levels of Group 1 were lower than in Group 2, but the difference was not statistically significant in this study. On histopathological evaluation of the anastomoses, no significant difference was observed between the groups, and as collagen typing was not performed, the data were not suitable for interpretation for ECM changes.

In conclusion, the tendencies in the parameters of both the fibrinolytic activity and wound healing in anastomosis obtained in our study are encouraging with respect to our hypothesis, but future studies performed with different blood volumes and evaluation times are required.

\section{REFERENCES}

1. Kanellos I, Blouhos K, Demetriades H, Pramateftakis MG, Mantzoros I, Zacharakis E, et al. The failed intraperitoneal colon anastomosis after colon resection. Tech Coloproctol 2004;8:53-5

2. Yamamoto Y, Wakabayashi G, Ando N, Aikawa N, Kitajima M. Increased fibrinolytic activity and body cavity coagula. Surg Today 2000;30:778-84.

3. te Velde EA, Wagenaar GT, Reijerkerk A, Roose-Girma M, Borel Rinkes IH, Voest EE, et al. Impaired healing of cutaneous wounds and colonic anastomoses in mice lacking thrombin-activatable fibrinolysis inhibitor. J Thromb Haemost 2003;1:2087-96.

4. Singer AJ, Clark RA. Cutaneous wound healing. N Engl J Med 1999;341:738-46.

5. Stumpf M, Klinge U, Wilms A, Zabrocki R, Rosch R, Junge $\mathrm{K}$, et al. Changes of the extracellular matrix as a risk factor for anastomotic leakage after large bowel surgery. Surgery 2005; 137:229-34.

6. Ehrlich HP, Tarver H, Hunt TK. Effects of vitamin A and glucocorticoids upon inflammation and collagen synthesis. Ann Surg 1973;177:222-7.

7. Lowry $\mathrm{OH}$, Rosebrough NJ, Farr AL, Randall RJ.. Protein measurement with the Folin phenol reagent. J Biol Chem 1951;193:265-75.

8. Reddy GK, Enwemeka CS. A simplified method for the analysis of hydroxyproline in biological tissues. Clin Biochem 1996;29:225-9.

9. Reijnen MM, Holmdahl L, Kooistra T, Falk P, Hendriks T, van Goor H. Time course of peritoneal tissue plasminogen activator after experimental colonic surgery: effect of hyaluronan-based antiadhesive agents and bacterial peritonitis. Br J Surg 2002;89:103-9.

10. Ivarsson ML, Bergström M, Eriksson E, Risberg B, Holmdahl L. Tissue markers as predictors of postoperative adhesions. Br J Surg 1998;85:1549-54.

11. Neudecker J, Junghans T, Raue W, Ziemer S, Schwenk W. Fibrinolytic capacity in peritoneal fluid after laparoscopic and conventional colorectal resection: data from a randomized controlled trial. Langenbecks Arch Surg 2005;390:5237.

12. Hellebrekers BW, Trimbos-Kemper GC, Bakkum EA, Trimbos JB, Declerck PJ, Kooistra T, et al. Short-term effect of surgical trauma on rat peritoneal fibrinolytic activity and its role in adhesion formation. Thromb Haemost 2000;84:87681.

13. Tarhan OR, Barut I, Sutcu R, Akdeniz Y, Akturk O. Pentoxifylline, a methyl xanthine derivative, reduces peritoneal adhesions and increases peritoneal fibrinolysis in rats. Tohoku J Exp Med 2006;209:249-55.

14. Akdeniz Y, Tarhan OR, Barut I. Can dexpanthenol prevent peritoneal adhesion formation? An experimental study. [Article in Turkish] Ulus Travma Acil Cerrahi Derg 2007;13:94100.

15. Mäkelä JT, Kiviniemi H, Laitinen S. Risk factors for anastomotic leakage after left-sided colorectal resection with rectal anastomosis. Dis Colon Rectum 2003;46:653-60.

16. Rullier E, Laurent C, Garrelon JL, Michel P, Saric J, Parneix M. Risk factors for anastomotic leakage after resection of rectal cancer. Br J Surg 1998;85:355-8.

17. Jiborn H, Ahonen J, Zederfeldt B. Healing of experimental colonic anastomoses. IV. Effect of suture technique on collagen metabolism in the colonic wall. Am J Surg 1980;139:40613. 
18. Braskén P, Renvall S, Sandberg M. Fibronectin and collagen gene expression in healing experimental colonic anastomoses. Br J Surg 1991;78:1048-52.

19. Ravanti L, Kähäri VM. Matrix metalloproteinases in wound repair (review). Int J Mol Med 2000;6:391-407.

20. Savage FJ, Lacombe DL, Boulos PB, Hembry RM. Role of matrix metalloproteinases in healing of colonic anastomosis. Dis Colon Rectum 1997;40:962-70.
21. Swaisgood CM, Schmitt D, Eaton D, Plow EF. In vivo regulation of plasminogen function by plasma carboxypeptidase B. J Clin Invest 2002;110:1275-82.

22. Cohen PA, Aarons CB, Gower AC, Stucchi AF, Leeman SE, Becker JM, et al. The effectiveness of a single intraperitoneal infusion of a neurokinin-1 receptor antagonist in reducing postoperative adhesion formation is time dependent. Surgery 2007;141:368-75. 